\title{
VARIABILITY OF SNOW DENSITY MEASUREMENTS IN THE RIO ESERA VALLEY, PYRENEES MOUNTAINS, SPAIN
}

\author{
S. R. FASSNACHT ${ }^{(1)}$, C. M. HEUN ${ }^{(2)}$, \\ J. I. LÓPEZ-MORENO(3) ${ }^{(3)}$ J. LATRON( $^{(4)}$ \\ (1) Watershed Science Program, \\ Colorado State University, Fort Collins, Colorado, USA 80523-1472 \\ (2) Natural Resources Management Program, \\ Colorado State University, Fort Collins, Colorado, USA 80523-1472 \\ (3) Instituto Pirenaico de Ecología, CSIC, \\ Campus de Aula Dei, P.O. Box 202 Zaragoza, 50080, Spain \\ (4) Department of Chemical and Agricultural Engineering and Agrifood Technology, \\ University of Girona, Girona 17071, Spain \\ Correo electrónico de contacto: srf@cnr.colostate.edu
}

\begin{abstract}
RESUMEN. Determinar con exactitud el espesor y densidad del manto de nieve resulta necesario para conocer su contenido de agua. La medición de la densidad resulta mucho más difícil y requiere más tiempo que la estimación de su espesor. En este trabajo se evalúa la variabilidad espacial de la densidad de la nieve en un tramo de 5.4 kilómetros en la cabecera del río Ésera (Pirineos Españoles). El sistema tradicional con un muestreador de nieve (snow tube sampler) es comparado con un sistema más laborioso, pero preciso, basado en la medición estratificada de la densidad a lo largo de toda la profundidad del manto de nieve. El primer método se basa en la extracción de una muestra de todo el manto de nieve con un tubo, y derivar su densidad mediante el conocimiento de el espesor y peso de la muestra. El segundo consiste en extraer muestras de un 1-L de volumen de nieve cada diez centímetros, desde la superficie nevada hasta el suelo. A mediados de enero, la variabilidad del manto de nieve no resulta sistemática espacialmente, y sólo puede ser explicada en las zonas de menor altura, donde el manto de nieve está próximo a condiciones de fusión, dada su proximidad a condiciones isotermas (próximo a los $0^{\circ} \mathrm{C}$ ). A finales de abril, los puntos de medición situados a menor altura también mostraron la mayor densidad.
\end{abstract}

ABSTRACT. An accurate assessment of snow depth and snow density is essential to determine that amount of water stored in the snowpack, i.e., snow water equivalent (SWE). The measurement of snow density is much more difficult and time consuming than snow depth. The variability in snow density is evaluated 
for a 5.4-km stretch of the Rio Esera headwaters in the Spanish Pyrenees Mountains. The traditional snow tube method is compared to the more labourintensive but accurate snow pit method. The former method measures snow depth and extracts a snow core that is weighed. The latter method uses a wedge cutter to extract a 1-L snow sample to estimate density at 10-cm intervals through the snowpack. The variability in snowpack density is not systematic and can only be explained at lower elevation when the snowpack is known to be melting, as identify by an isothermal snowpack at zero degrees Celsius. This occurred during a mid-January survey. A late-April survey showed that these lower elevation sites were still more dense.

Palabras clave: densidad de nieve, equivalente de agua en forma de nieve, Valle del Ésera, Pirineos.

Key words: snow density, snow water equivalent, Ésera Valley, Pyrenees Mountains.

Enviado el 10 de octubre de 2009

Aceptado el 21 de enero de 2010

\section{Introduction and Background}

Snow is an important storage of water across watersheds with headwaters located in high elevation or latitude areas. The number of meteorological stations, especially those with snow monitoring capabilities, is low and the distribution of snow in such domains can be quite variable making the estimation of storage volumes challenging. The mass of snow at a point is referred to as snow water equivalent (SWE) and is a product of the snow depth and depth-averaged density. Manually, snow depth is more easily measured than SWE or density. Traditionally measurements of snow density are gathered by determining depth and weighing an extract a snow core for SWE using a snow tube, such as a Mount Rose, Federal Sampler (Goodison et al., 1981). For research purpose, a more labour-intensive process requires the digging of a snow pit and using a wedge cutter (typically $1 \mathrm{~L}$ ) to extract density samples at a $10 \mathrm{~cm}$ interval. Automatically, snow depth is measured using ultra-sonic depth sensors (e.g., Ryan et al., 2008), while SWE is measured using a snow pillow (Goodison et al., 1981).

For a shallow snowpack, depth has been shown to be more variable than density (Logan, 1973). This assumption has been used by Elder et al. (1991) and in most subsequent snow surveys in montane regions, thus the number of SWE and/or density samples required is decreased. Rovansek et al. (1993) recommended that 14 depth measurements could be made per SWE measurement for the North Slope of Alaska, United States. This paper investigates the variability of snowpack density and compares snow tube and snow pit sampling methods. Specifically, the research questions are 1) what is the variability of density over a given space? If it is supported that density does vary over space, can it be attributed to elevation? 2) Is the snow tube sampling method a substitute for the customary wedge cutting method? 


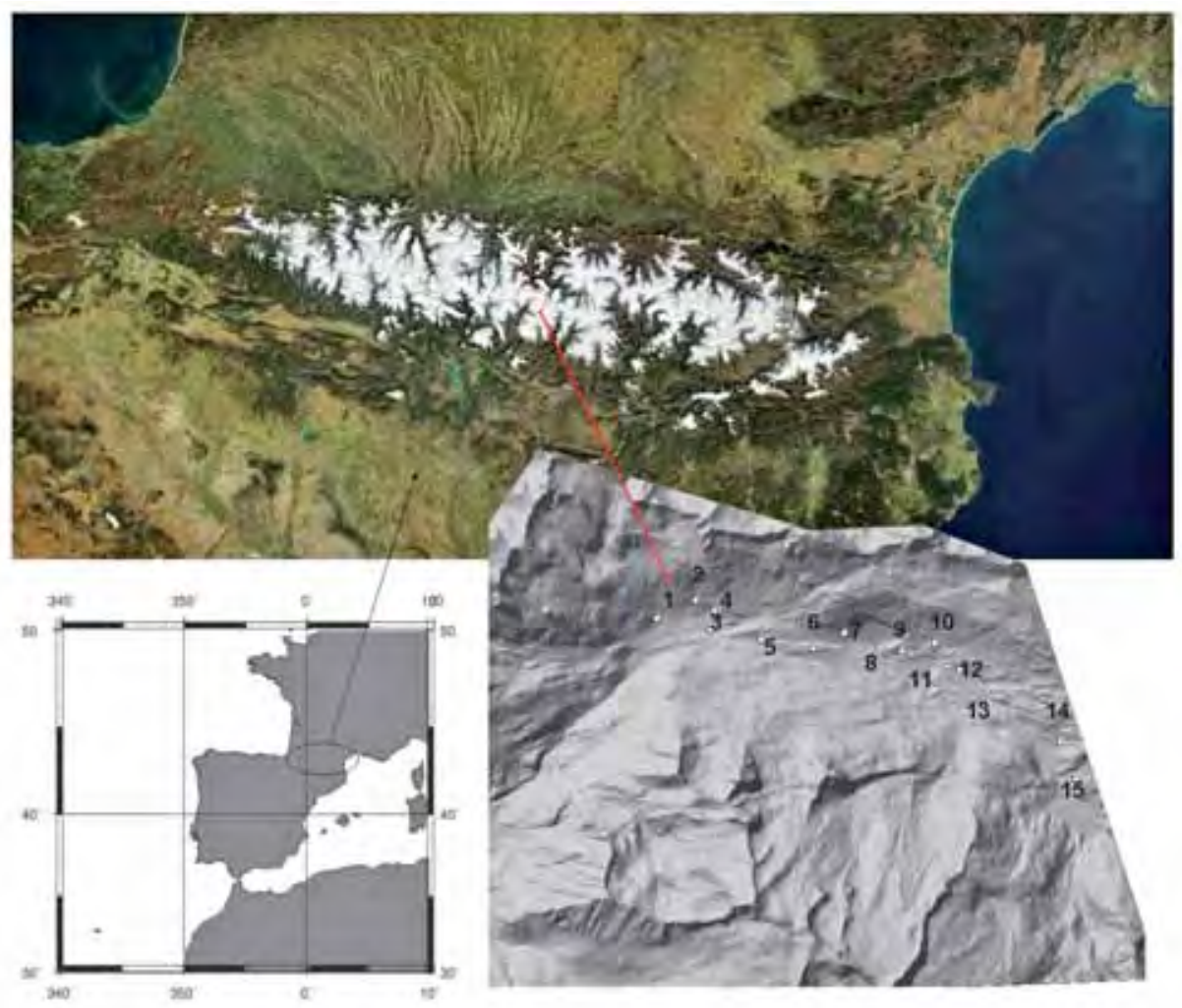

Figure 1. Location map.

\section{Study Site}

Snow surveys were conducted in the headwaters of the Rio Ésera in the Central Spanish Pyrenees Mountains (Figure 1) in mid-January $\left(12^{\text {th }}\right.$ to $\left.16^{\text {th }}\right)$ and at the end of April $\left(21^{\text {st }}\right.$ to $\left.24^{\text {th }}\right)$ of 2009 . The dates represented contrasted periods in terms of the snowpack. In January, most of the snowpack is still accumulating and has a somewhat homogeneous snow distribution. Low incoming solar radiation and the cold temperature during accumulation should have maintained a strong thermal gradient through the snowpack. In April, incoming radiation is higher yielding possible snowpack differences in forest openings compared to wide open areas. Some areas should be ablating while others should be near their peak accumulation or still accumulating. The snowpack in most locations should be isothermal at zero degrees Celsius.

Density was sampled at 15 locations over a distance of 5380 metres and an elevation range of 344 metres from 1735 to 2074 metres above sea level (Fig. 1). Individual sampling locations were selected under the condition that surface of each appeared homogeneous over a 10 by 10 metre plot. Eight locations were in forest openings (size of 
the open area was less than twice the height of the surrounding trees) and seven in open areas (size of the open area is higher than five times the height of the surrounding trees).

\section{Methodology}

\subsection{Sampling and Data Collection}

In January, a snow pit was dug to the ground at each location. Density was measured following the procedure of Elder et al. (1991). Snow samples were taken at $10 \mathrm{~cm}$ intervals through the height of the pit using a $1 \mathrm{~L}$ metal wedge cutter and weighed on a digital scale to the near gram (Photo 1a). The scale had been tared with the cutter. Two samples were taken at each interval, with additional samples being extracted if the difference between samples was greater than 20 grams. The weight of each sample directly yielded a density in kilograms per cubic metre. An average density was computed for each $10-\mathrm{cm}$ interval, with the bottom interval scaled to consider that the total snow depth was not a multiple of 10. A snow pit average density was then computed. The snowpack temperature was measured at a 10-cm interval. Snow pits were not dug in April and thus no snow pit densities were measured.

For the snow tube measurements in January, we crafted a custom snow tube by cutting $1-\mathrm{cm}$ teeth into a $6.9-\mathrm{cm}$ diameter PVC pipe. After the snow pit had been dug, this tube was carefully turned into the snowpack by applying a downward force. Since we were in the snow pit while inserting the tube we knew when dense melt-freeze layers were encountered and increased the turning to cut through these layers. Upon reaching the bottom of the snow pit, an $8-\mathrm{cm}$ wide thin $(<1 \mathrm{~mm})$, but rigid, plastic mat was pushed along the snow-soil interface to cap the snow tube. The snow tube was extracted from the snowpack, the snow core was poured into a container and weighed. The mass of any soil present was also weighed and deducted from the mass of the snow core. This mass was converted into SWE and using the depth of snow where the core was extracted the snow tube density was computed. Five snow tube density measurements were made at each location, except the lowest location where only four measurements were made.

In April, the SnowHydro (2004) SWE coring tube was used (Photo 1b). This is a 2-m long clear lexan tube with metal cutting teeth on the bottom. It is similar to the Adirondack or Meteorological Service of Canada snow samplers (see Goodison et al., 1981 for information on those samplers). As with the Federal Sampler, the SnowHydro sampler is used with a scale calibration to directly measure SWE. At six locations, two samples were taken while at eight locations three samples were taken. Four samples were taken at the third lowest location.

\subsection{Data Analysis}

The variation of snowpack density was investigated over the range of elevations surveyed. For the January measurements, the average density derived from snow pit was 

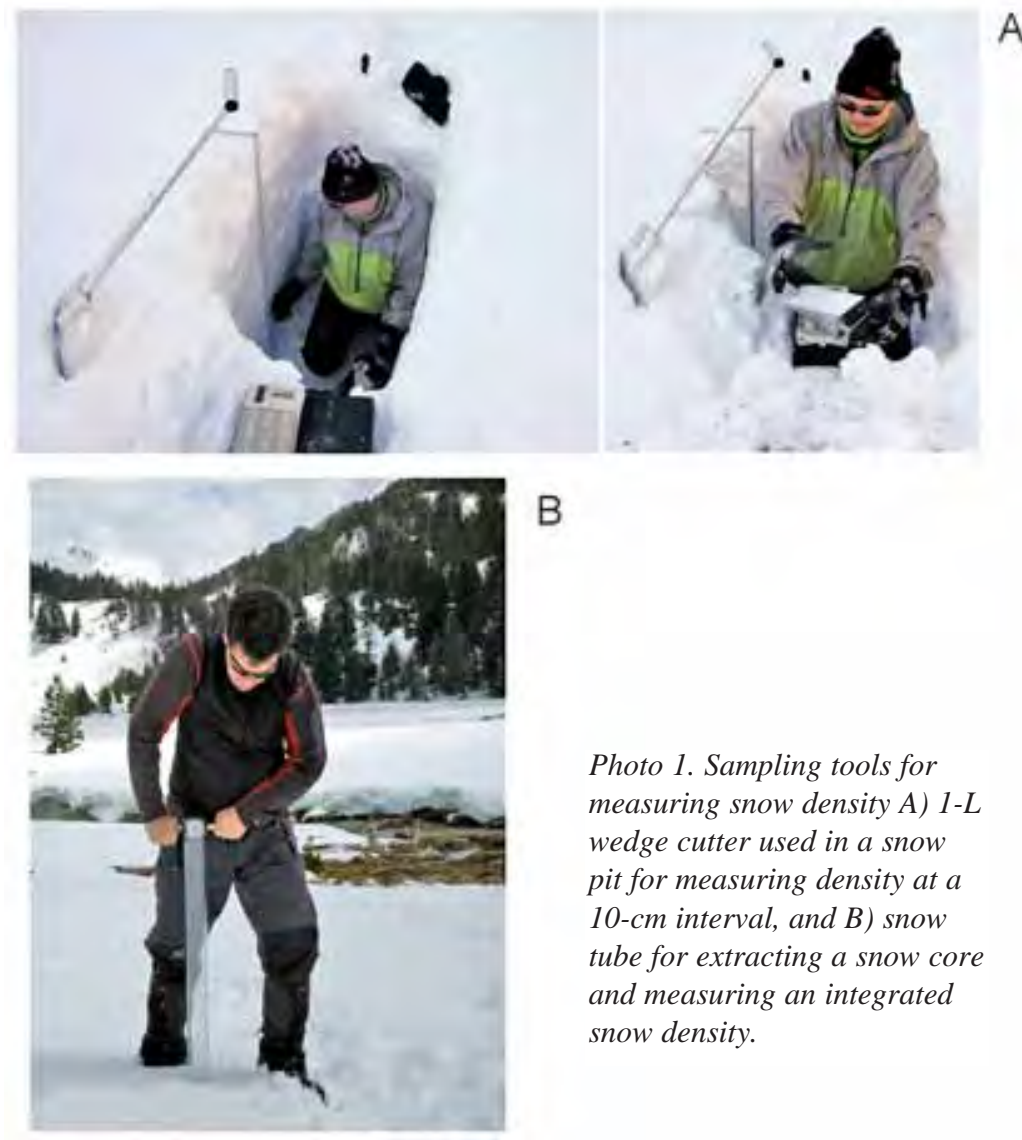

$B$

Photo 1. Sampling tools for measuring snow density A) 1-L wedge cutter used in a snow pit for measuring density at a 10-cm interval, and B) snow tube for extracting a snow core and measuring an integrated snow density.

compared to that obtained from the snow tube sampling. The maximum and minimum measurements for each snow pit interval and for each set of snow tube measurements was used to determine measurement variability. We assessed the incremental snow pit density. To assess variation in depth versus the differences in the measurements over each sampling location, SWE was computed at each location. The SWE was investigated over the surveyed elevation range. We used the depth from the density measurement compared to the depth from 121 points taken around the density measurements over a 10 by 10 metre plot.

\section{Results}

In January there is no obvious relationship in average density and elevation, with the exception of the lowest three locations (Fig. 2a), for which the density increases as elevation decreases. In April these three locations and the fourth lowest location vary from the remaining 11 locations that show no obvious relationship between average density and elevation. The fourth location is least dense in January but most dense in April. 


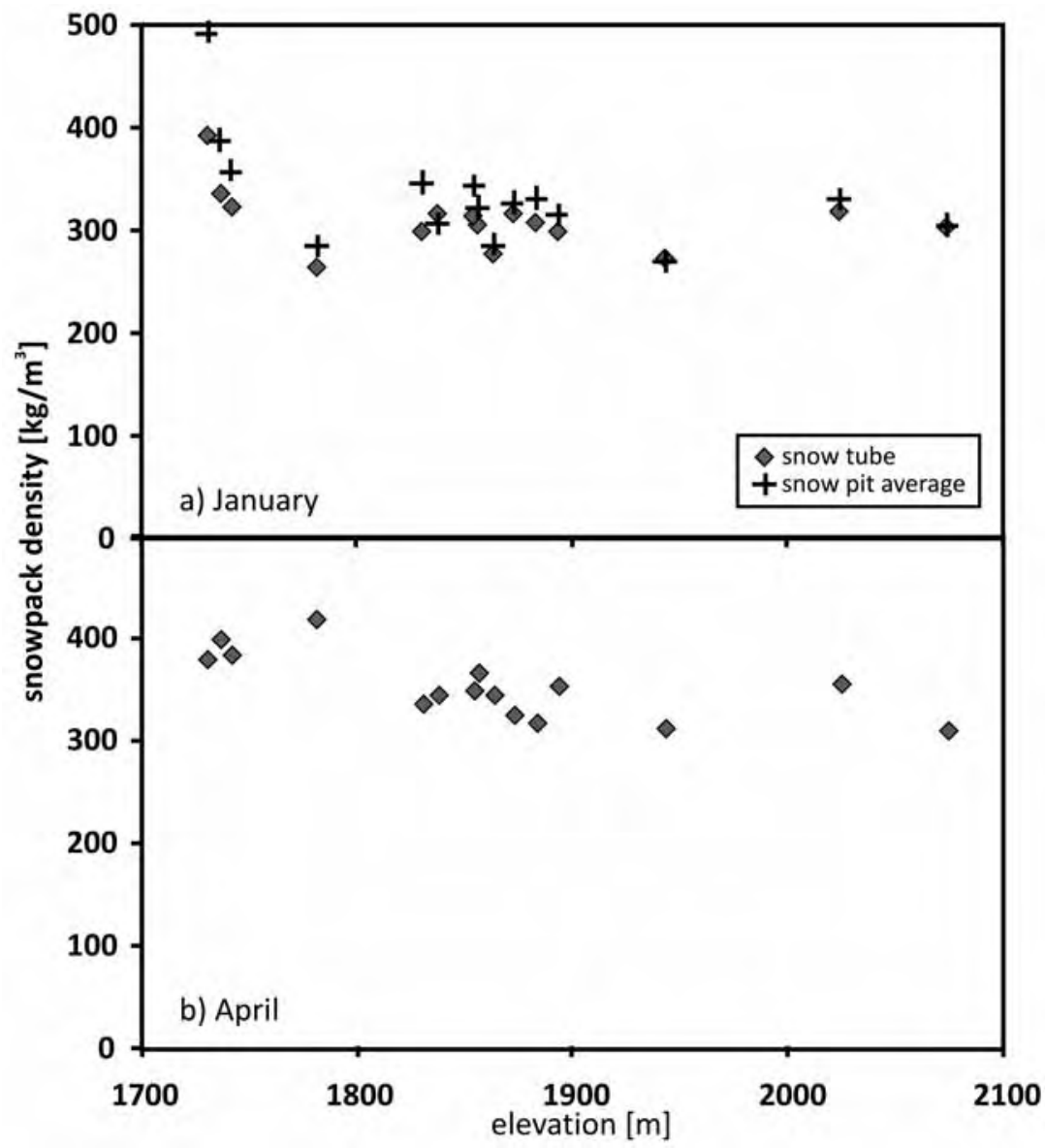

Figure 2. Variation of snowpack density over the surveyed range of elevations. The January measurements (a) include the average density derived from snow pit and snow tube sampling, and $b$ ) the April measurements are from the snow tube.

For a lesser dense snowpack, the average snow tube density was similar, yet slightly less, than the snow pit density (Fig. 3). The two lowest elevation samples were most variable; when a linear regression was fit through all data, the slope was only 59\%. For these locations, the snow tube samples remained less dense, even considering the measurement variation. When these two locations were removed, the slope remained less than $100 \%$, but the density variation was low. These two locations and the next dense location, as highlighted above in Figure 2a, are isothermal at zero degrees Celsius (Fig. 4) and melting had started. Otherwise, the average snowpack temperature decreased as elevation increased (Fig. 4). Open areas tended to be colder than forest openings.

The average snow tube density for the 15 locations was $310 \mathrm{~kg} / \mathrm{m}^{3}$ with an average for the seven forest openings of $302 \mathrm{~kg} / \mathrm{m}^{3}$ and the eight open areas of $316 \mathrm{~kg} / \mathrm{m}^{3}$. 


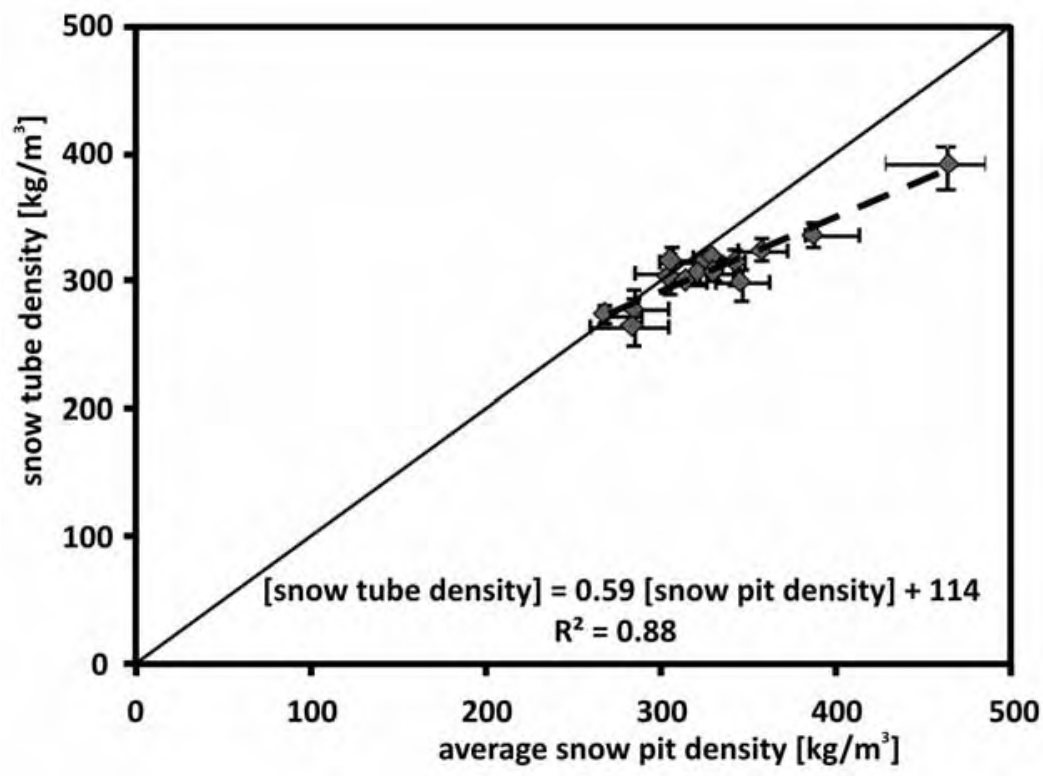

Figure 3. Comparison of snow tube and snow pit average density with error bars representing the maximum and minimum measurements.

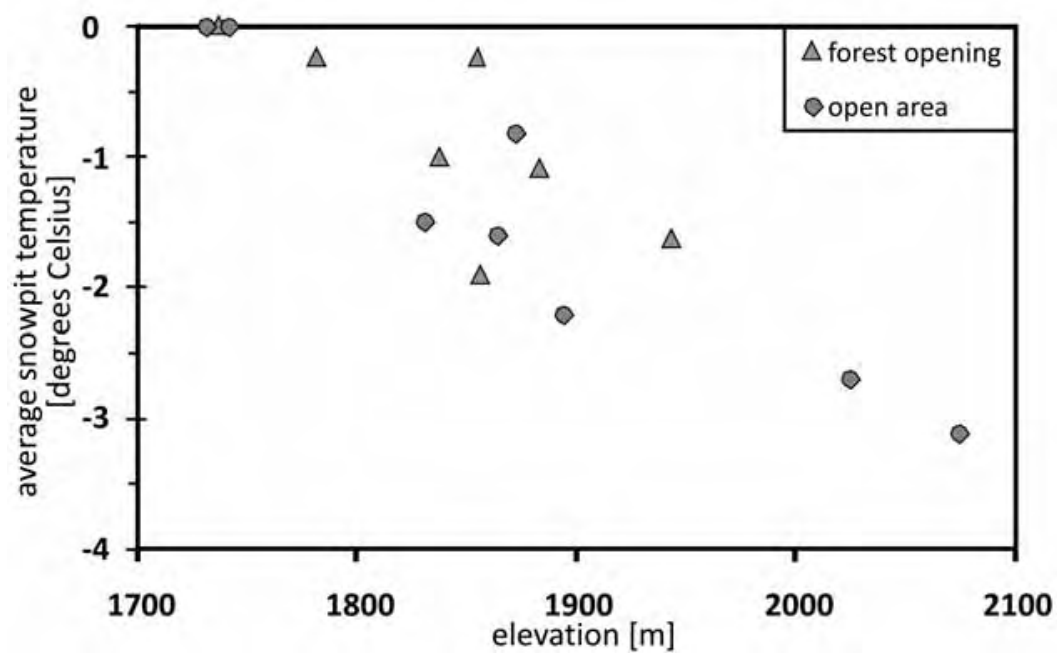

Figure 4. Average snow pack temperature from 10-cm snow pit measurements, excluding the top $15 \mathrm{~cm}$, versus elevation. 


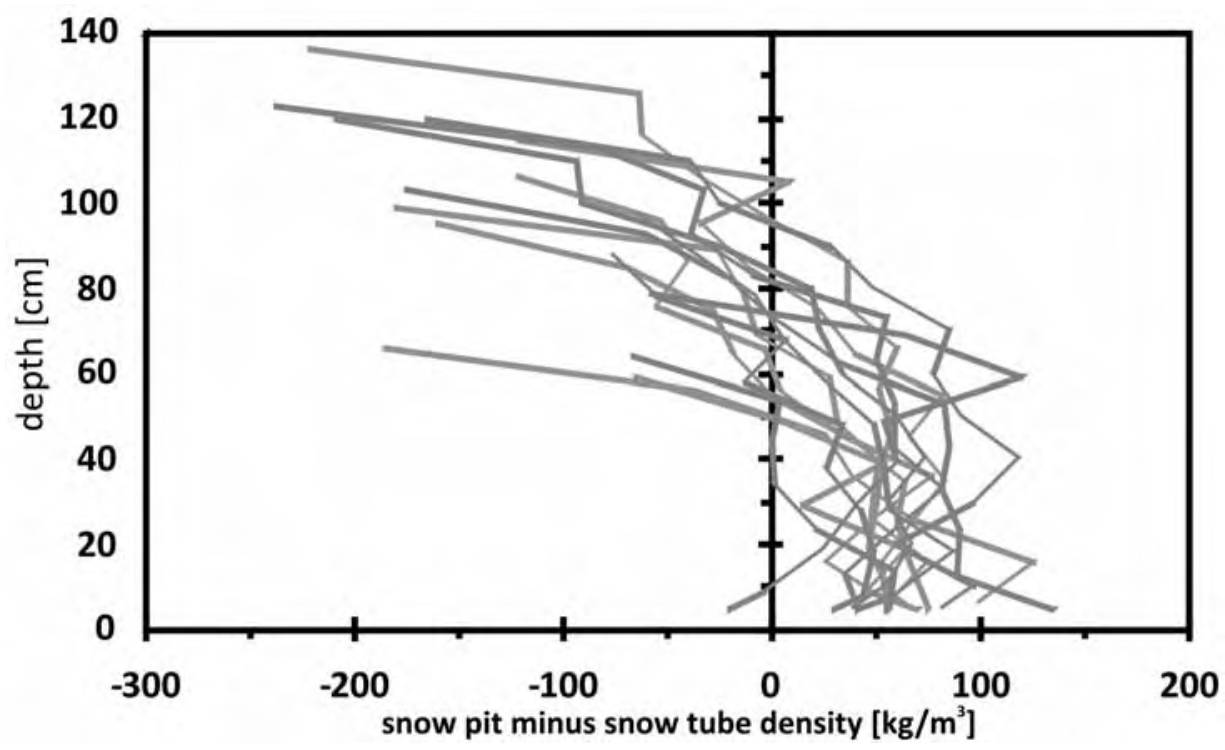

Figure 5. The difference between incremental snow pit density and the depth-average snow tube density over depth.

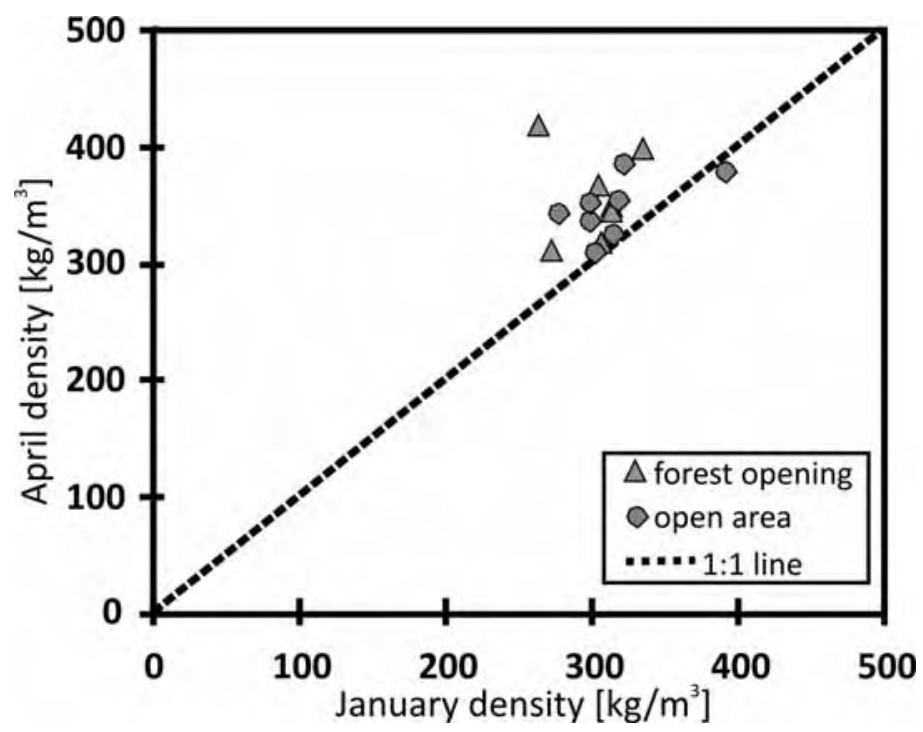

Figure 6. Comparison of April versus January snow tube density. 


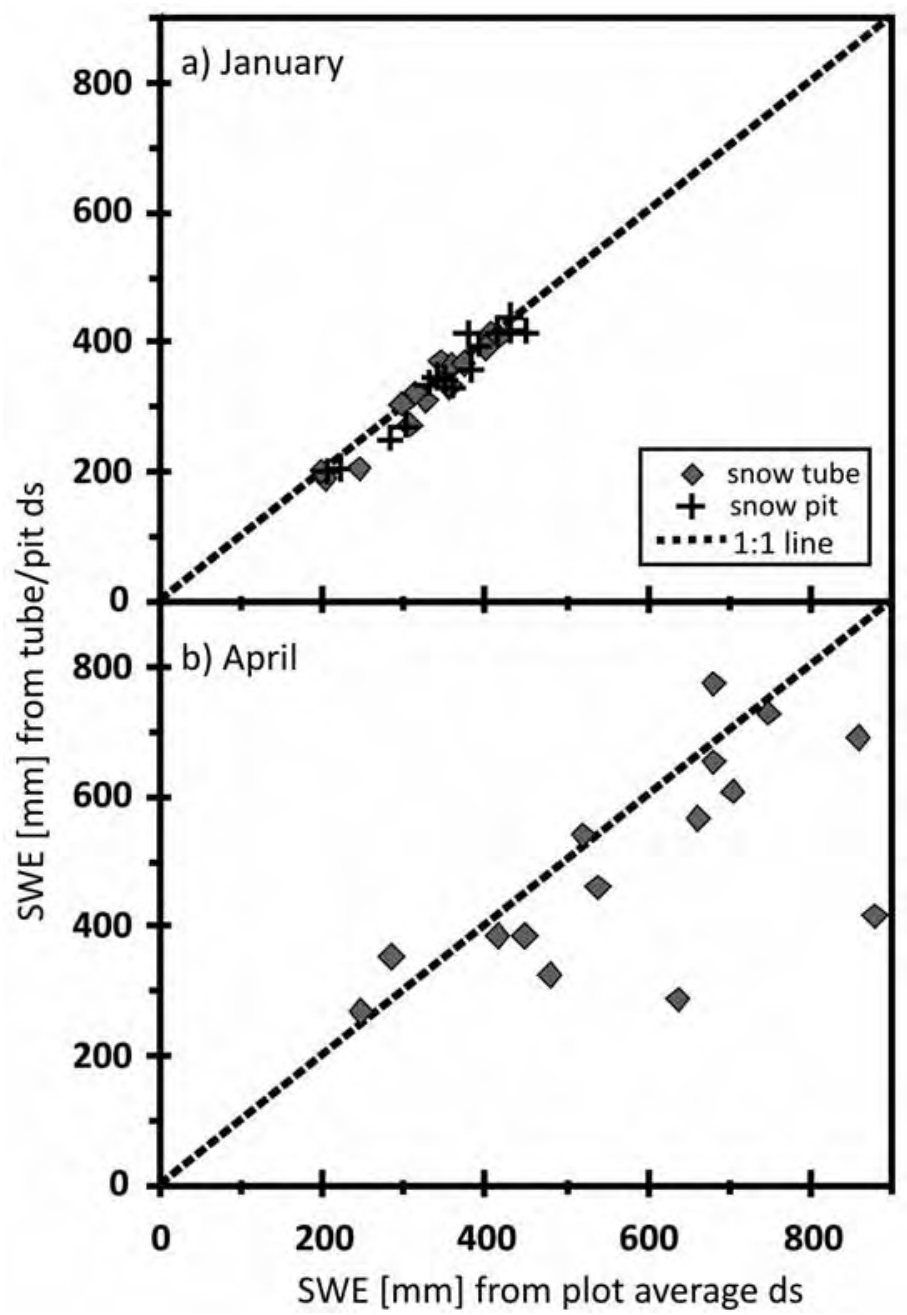

Figure 7. Comparison of SWE computed using the snow tube (snow pit) depth (1 to 5) measurements versus those computed from the average of the plot depth (121) measurements for a) January and b) April.

As above (Fig. 3), the average snow pit density was greater at 331,340 , and $320 \mathrm{~kg} / \mathrm{m}^{3}$ for all locations, forest openings, and open areas, respectively. The density in the snowpack varied with depth (Fig. 5) with less dense fresh snow at the top of the pack and metamorphosed crystals below. Some depth hoar was present at the bottom of the snowpack yielding less dense layers.

The average snow tube density was greater in April than in January (Fig. 6), except for the first location (392 versus $378 \mathrm{~kg} / \mathrm{m}^{3}$ ), which was melting during the January 


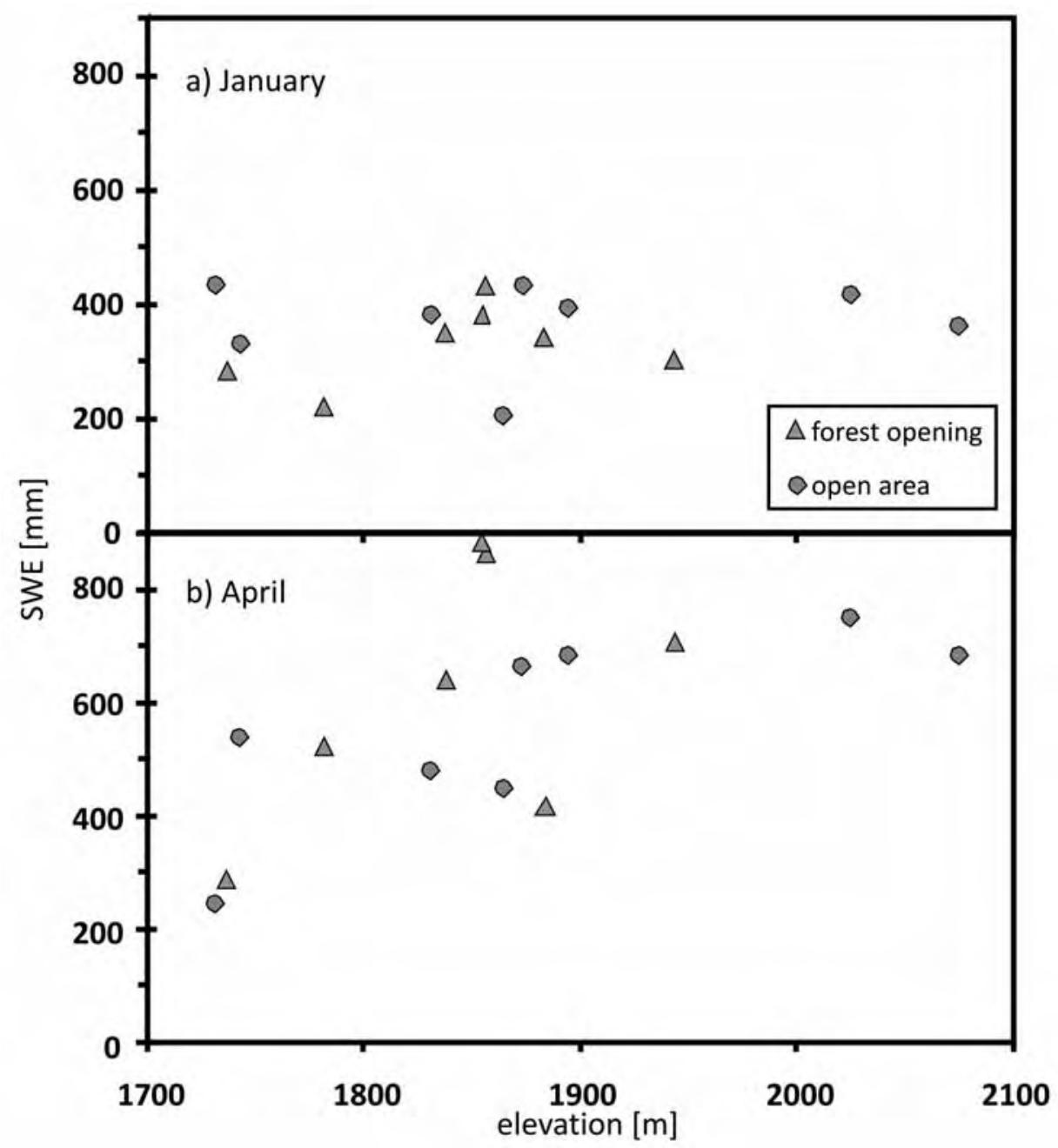

Figure 8. Variation of computed SWE (average density times average plot depth) versus elevation for a) January and b) April.

survey. The samplers were different between surveys, with the SnowHydro sampler assumed to be more accurate due to its metal cutting teeth. As mentioned previously the fourth lowest point had the lowest density in January $\left(264 \mathrm{~kg} / \mathrm{m}^{3}\right)$ and highest in April $\left(419 \mathrm{~kg} / \mathrm{m}^{3}\right)$ yielding the largest difference in Figure 6.

In January the SWE computed using the different depths are almost identical for both the snow tube and the snow pit (Fig. 7a). However, in April SWE from the plot average depth using 121 points tends to be greater than from the 5 depth measurements using the snow tube (Fig. 7b). In only two locations was the computed SWE less. 


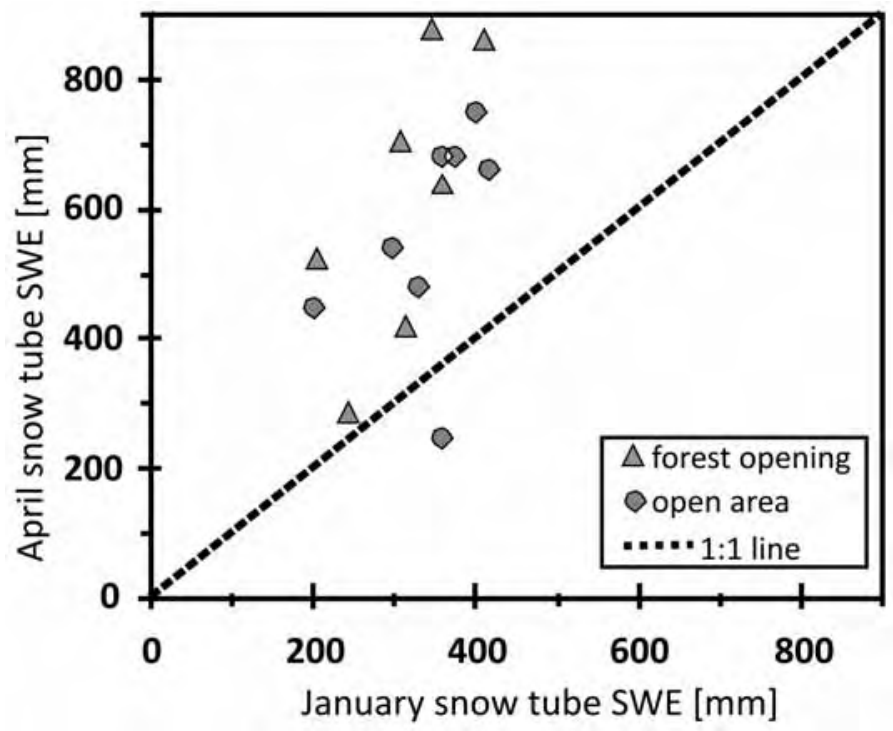

Figure 9. Comparison of April versus January snow tube SWE.

In January, SWE did not vary with elevation (Fig. 8a) with SWE ranging from 205 to $431 \mathrm{~mm}$. In April, SWE was limited at the lowest two elevations (247 and $285 \mathrm{~mm}$ for first and second lowest locations), but no discernible pattern for the other locations ranging from 416 to $881 \mathrm{~mm}$ of SWE (Fig. 8b). There was less snow at the lowest elevation location in April than January (358 vs. $247 \mathrm{~mm}$ ) and almost the same at the second lowest location (246 vs. $285 \mathrm{~mm}$ ). There was more snow at all other locations (Fig. 9).

\section{Discussion}

For shallow snowpacks, snow density has been shown to be conservative, varying little over space were redistribution is limited (Dickinson and Whiteley, 1972; Logan, 1973). Where winds are greater and create wind slabs and depositional zones, snowpack density variability can be substantial (Sturm and Holmgren, 1998). There was limited variability in snowpack density for the January and April measurements (Fig. 2a and 2b). The similarities in density across the study site could be a product of the consistencies in snowpack on both the local and landscape level that express a heterogeneity in factors such as topography, vegetation, microclimate, and redistribution and melting (López-Moreno et al., 2007).

For the Canadian Prairies, Pomeroy and Gray (1995) estimated density as a function of depth for shallow snowpacks, while for the Swiss Alps Jonas et al. (2009) used a power function over a range of snow depths up to $3.5 \mathrm{~m}$. There was no obvious relationship between depth and density for the Rio Esera area, with a possible decrease 
in density as depth increase in April. However, there is a difference in SWE computed using the snow tube depth measurements versus using the 121 plot depth measurements (Fig. 7b). This is due to the limited number of density measurements ( 2 to 4 ) per location in April. Depth tends to vary more at a local scale later in the winter and it is recommended that more snow tube density measurements should be taken at each location. If this is not possible, it is recommended that additional snow depth measurements should supplement density measurements.

For the Swiss Alps, Jonas et al. (2009) showed that on average early in the winter (early accumulation) density was less at lower elevations while later in the winter (ablation) density was more at lower elevations. This study showed limited trends in density over elevation; the increase in snowpack density could only be explained when the snowpack was isothermal and showed signs of melting (Fig. 4). The lowest three locations were most dense during both sampling dates. Most research has shown that snow accumulation increases with elevation (e.g., Fassnacht et al., 2003 over large scales), but the average increase in snow is quite variable (Meiman, 1968). While elevation tends to be most important topographic variable related to SWE or depth, numerous other topographic variables are relevant at different scales depending upon the location (e.g., Elder et al., 1991; Fassnacht et al., 2003; López-Moreno et al., 2007). Therefore, it is recommended that density be sampled at more locations and that other topographic variables should be considered to explain density variations.

The time required to sample density in a snow pit is a function of snow depth due to pit excavation, sampling, and pit refilling, with experience in continental snow pits (especially in Colorado, United States) showing that the exercise requires approximately one hour per metre of depth. Also, snow density sampling is a destructive procedure and the footprint of a snow pit is a function of depth $\left(\sim 0.5 \mathrm{~m}^{2}\right.$ per metre of depth). The footprint of snow tube sample is much smaller and sampling can require less than five minutes per sample. Therefore it is recommended that a number of snow tube samples should be taken at each location and due to the variation in depth, several samples should be taken close together in at least two sets that are 5 to 10 metres apart. The snow tube sampling should be supplemented by snow pit measurements. The snow pit can be used to determine if the snowpack is isothermal and melting. Snow tube samples are underestimated in denser snow or overestimated in less dense snow for shallower snowpacks (Goodison, 1978) while in a wet, deep snowpack (California, United States) the Federal Sampler snow tube overestimated density (Peterson and Brown, 1975). Therefore, a combination of snow tube and snow pit sampling should improve density estimation. With a combination of density (or SWE) and depth measurements over an area an optimal ratio of depth to density measurements can be determined, as per Rovansek et al. (1993).

\section{Conclusions}

Along a 5-km section of the Rio Esera, there is variation in snowpack density, but with no discernible pattern. The lowest three of 15 sampling locations tended to have a higher density. In January, the snowpack at these locations was isothermal and had 
started to melt. It is recommended that density should be measured across any new study area due to the uncertainty in density variation.

When the snowpack was melting, i.e., the lowest three locations in January, the snow tube underestimated density compared to the snow pit wedge cutter method. The two sets of density measurements at the other 12 locations were similar. It is recommended that for any snow survey in a new area, both methods should be used to balance the accuracy (snow pit) with the rate of sampling, which is much faster for the snow tube. Once the measurement techniques have been compared for different times over a winter, a specific density sampling strategy can be determined. Snow pits are recommended for locations where the snowpack has started to ablate.

\section{Acknowledgements}

This work was supported by research projects CGL2006-11619/HID, CGL200801189/BTE, and CGL2008-1083/CLI, financed by the Spanish Commission of Science and Technology, and FEDER, EUROGEOSS (FP7-ENV-2008-1-226487), and the project "Las sequías climáticas en la cuenca del Ebro y su respuesta hidrológica" and "La nieve en el Pirineo aragonés: distribución espacial y su respuesta a las condiciones climáticas", financed by "Obra Social La Caixa" and the Aragón Government, and "Programa de grupos de investigación consolidados", financed by the Aragón Government. Data collected was assisted by Gonzalo López, Pablo Corella and Mario Morellón; their efforts are acknowledged with thanks.

\section{References}

Elder, K., Dozier, J., Michaelsen, J. (1991). Snow accumulation and distribution in an alpine watershed. Water Resources Research, 27(7): 1.541-1.552.

Dickinson, W. T., Whiteley, H. R. (1972). A sampling scheme for shallow snowpacks. IAHS Bulletin, 17(3): 247-258.

Fassnacht, S. R., Dressler, K. A., Bales, R. C. (2003). Snow water equivalent interpolation for the Colorado River Basin from snow telemetry (SNOTEL) data. Water Resources Research, 39(8): 1208 [doi:10.1029/2002WR001512].

Goodison, B. E. (1978). Accuracy of Snow Samplers for Measuring Shallow Snow Packs: An Update. Proc. of 35th Annual Eastern Snow Conference, Hanover, NH.

Goodison, B. E., Ferguson, H. L., McKay, G. A. (1981). Measurement and Data Analysis. Chapter 6 in Handbook of Snow, (eds. Gray, D. M. and Male, D. H.), Pergamon Press Canada Ltd., 191-274.

Jonas, T., Marty, C., Magnusson, J. (2009). Estimating the snow water equivalent from snow depth measurements in the Swiss Alps. Journal of Hydrology, 378: 161-167. 
LoGAN, L.A. (1973). Basin-wide water equivalent estimation from snowpack depth measurements. IAHS Publication, 107: 864-884.

López-Moreno J. I., Vicente-SERrano, S. M., LANJeri, S. (2007). Mapping of snowpack distribution over large areas using GIS and interpolation techniques. Climate Research, 33(3): 257-270.

Meiman, J. R. (1968). Snow Accumulation Related to Elevation, Aspect, and Forest Canopy. Proc. of Snow Hydrology: Proceedings of the Workshop Seminar, sponsored by the Canadian National Committee for the International Hydrological Decade, pp. 35-47.

Peterson, N. R., Brown, A. J. (1975). Accuracy of Snow Measurements. Proceedings of $43^{\text {rd }}$ Western Snow Conference, Coronado, California, pp. 1-5.

Pomeroy, J. W., Gray, D. M. (1995). Snow Accumulation, Relocation and Management. National Hydrology Research Institute Science Report No. 7, 144 pp.

RovanseK, R. J., KANE, D. L., Hinzman, L. D. (1993). Improving estimates of snowpack water equivalent using double sampling. Proceedings of the $61^{\text {st }}$ Western Snow Conference, Quebec City, Quebec, pp. 157-163.

Ryan, W. A., Doesken, N. J., Fassnacht, S. R. (2008). Evaluation of ultrasonic snow depth sensors for U.S. snow measurements. Journal of Atmospheric and Oceanic Technology, 25(5), 667-684.

SNOw-HYDRo (2004). Snow-Hydro. URL: <http://www.snowhydro.com/>, last accessed November 20, 2009.

Sturm, M., Holmgren, J. (1998). Differences in compaction behaviour of three climate classes of snow. Annals of Glaciology, 26, 125-130. 